\title{
Analysis of Work Posture and Manual Material Handling in a Flour Production Process
}

\author{
Hafidh Munawir *, Rengganis Ernia Wulansari, Eko Setiawan, Much Djunaidi \\ Industial Engineering Department, Universitas Muhammadiyah Surakarta, Surakarta, Indonesia \\ *Corresponding Author:hafidh.munawir@ums.ac.id
}

\begin{abstract}
The workers in UD Jaya Group, a small flour producer located in Klaten District, Central Java, Indonesia, complained of having muscle pain or musculoskeletal disorders in the calf, knee, wrist, arm, waist, shoulder, back, and neck because there were variety of activities that required the workers to perform non-ergonomic work postures. This pain resulted in a decrease of work productivity, potentially caused work accidents, and affected the health of the workers. The purpose of the research is to analyze the work postures and to reduce musculoskeletal disorders caused by the non-ergonomic work postures among UDJaya Group workers. In achieving the purpose, a post-work analysis was performed on the work postures and the manual handling processes by using the Rapid Entire Body Assessment (REBA) method and the Manual Activity Chart (MAC) Tool. Based on the REBA assessment on 18 work activities, there was 1 working activity that was classified as an action level 1 , 15 working activities were classified as the action level 2, and 2 working activities were classified as the action level 3. Based on the MAC Tool assessment on 11 work activities, 10 working activities were classified as the action level 2 and 1 working activity was classified as the action level 4 . The recommendations were to reduce the weight of the load, increase the number of lamps and provide aiding tools.
\end{abstract}

Key words : Manual Handling Assessment Chart Tool, Musculoskeletal Disorders, Rapid Entire Body Assessment, Work Posture

\section{INTRODUCTION}

The availability of flour in Indonesia is required to improve the food industrial sector that continues to grow. According to Djoni Wibowo[1] flour is a solid granule of which concentration is smooth to very fine according to its use.Flour utility varies greatly as it is used as an object of research, industrial raw materials, and household items.

Flour suppliers in Indonesia consist of large companies and small and medium enterprises (SMEs). The process of making flour in SMEs uses simple machines with a large contribution of physical activities of human labor, especially in manual material handling.
Manual material handling is the most common cause of the workers experiencing fatigue, spinal cord injuries, and waist injuries. Among several manual material handling activities, lifting operations are proven to be one of the highest causes of workers experiencing injuries [2]. The process of manual work with non-ergonomic work postures is very risky to cause musculoskeletal disorders or muscle pain [3].

Musculoskeletal discomfort is the complaints of mild to severe pain in the skeletal muscle. When muscles lift static loads repeatedly for a long time, they may damage the joints, tendons, and ligaments [4]. The health problem-related study conducted to 9482 workers in 12 districts/cities throughout Indonesia by the Ministry of Health, Republic of Indonesia, in 2006 [5] revealed that approximately $40.5 \%$ of Indonesian workers felt the health problem was strongly influenced by the type of work they performed. It is found in the study that the four most common health problems suffered by the workers were musculoskeletal disorder (16\%), neurological disorders (6\%), cardiovascular (8\%), and ENT disorders (1.5\%). Work-related Musculoskeletal Disorders (WMSDs) led to decreasing product/job quality and worker productivity as well as increasing costs [6].

Ergonomic workplace design has a focus on reducing exposure to hazards in the musculoskeletal system, including symptoms and related disorders. Therefore, the work assessment carried out manually is very important to estimate the health risks of employees and as a preventive strategy to reduce such exposure [7]. Ergonomics aims to design the workplace so that the worksite is suitable according to the needs and physical abilities of the workers, rather than physically forcing the worker's body to fit the job [8]. The application of ergonomic principles will help in improving the performance and productivity of the workers and for assisting the operator to feel safe and comfortable [9]. The working position that does not meet the application of ergonomics potentially causes musculoskeletal discomfort, muscle pain, and fatigue. Several factors such as repetitive activities, excessive muscle stretching, awkward work posture, combined causes, and secondary causes cause a person to suffer musculoskeletal disorders [4].

UD Jaya Group is a small and medium enterprise (SME) located in Klaten, Central Java, Indonesia. The company produces corn flour and palm flour. The flour production 
process at UD Jaya Group uses machinery and human labor. In the company, a variety of activities requires the workers to perform work postures that are not ergonomic. The activities are dominated by manual material handling one. During the research conducted by the authors, there were 5 work stations in UD Jaya Group namely washing, grinding, drying, smoothing and packing work stations. Based on the observations at UD Jaya Group using the Nordic Body Map questionnaire, the workers complained of having muscle pain or musculoskeletal disorders in the calves, knees, wrists, arms, waist, shoulders, back, and neck. The Pain resulted in a decrease of work productivity, which potentially caused work accidents and affected the health of the workers.

Several studies related to work posture assessment in order to reduce musculoskeletal discomfort have been conducted in small and medium enterprises (SMEs) in Indonesia. These include those on the paving and bricks manufacturing process [10] and on metal casting process [11]. However, there are only a few studies that consider manual material handling assessment in small and medium enterprises as the main factor that causes musculoskeletal discomfort among the workers. The study is conducted to analyze the working postures and the manual material handling processes using Rapid Entire Body Assessment (REBA) and Manual Activity Chart (MAC) Tool. The objective of the study is to analyze the work postures and manual material handling in flour production process among UD Jaya Group workers to reduce musculoskeletal disorders caused by the non-ergonomic work postures.

\section{LITERATURE REVIEW}

\subsection{Ergonomic}

The implementation of the ergonomics principle in the design of work systems can create a balance between the task's demands and the worker's characteristics. This can also provide the worker's safety, increase the worker's productivity, and give job satisfaction and the worker's physical and mental well-being [12]. The mining company in Russia started to apply ergonomics to enhance the worker's safety as human error has been a key factor in coal industrial accidents [13]. A study on ergonomics intervention by Esmaeilzadeh and associates [14] showed that after over 6 months of ergonomics intervention, the intensity, duration, and frequency of work-related upper extremity musculoskeletal disorders (WUEMSDs) symptoms among computer workers decreased significantly.

\subsection{Manual material handling (MMH)}

Manual material handling (MMH) includes the activity of handling, moving, lifting, and carrying materials with the absence of mechanical tools [15]. The object's weight is an important factor but other factors are at risk of causing injury to the workers, such as the frequency of carrying out the manual handling activities, the location of objects when picking up or putting down the objects, the distance of carrying the objects, bending, and others. The manual material handling activities that are designed with the appropriate principles can improve work performance and reduce incidents, costs, and accidents, while the manual material handling activities that are designed incorrectly can cause musculoskeletal disorders [16]. Having done research in the rice mill industry, Astuti [17] reported that the workers in the industry experienced musculoskeletal discomfort on the neck, shoulders, arms, wrist, thigh, and knee due to unnatural work posture on the manual material handling process.

\subsection{Musculoskeletal Disorders (MSDs)}

In Grandjean's opinion [4], musculoskeletal discomforts are complaints of pain felt by workers in the skeletal muscle area. Musculoskeletal disorders include a wide range of inflammatory conditions and a decrease in muscle function, peripheral nerves, tendons, joints, ligaments, and supporting blood vessels [18]. Many human tasks have the possibility of causing musculoskeletal disorders among the workers in some various fields related to their tasks. Some of the tasks include reaching, lifting, carrying/ transporting, repetitive movements, maintenance, climbing, working in the same position continuously (sitting or standing), and others [19]. Musculoskeletal disorders are common among workers in various fields, such as nurses in hospitals [20], construction workers [21], and office workers [22]. Recent study results showed MSDs are the main contributors of productivity loss [23], long-lasting disability [24], and functional impairment [25].

\section{METHODOLOGY}

The study was conducted on the flour production process of washing, milling, drying, smoothing and packing work stations at UD Jaya Group located in Klaten, Central Java, Indonesia. The sample of this research is workers who have worked for more than 3 years in a particular work station. This study identifies work postures using the Rapid Entire Body Assessment (REBA) method and evaluates manual material handling using the Manual Handling Assessment Chart (MAC Tool) method.

The Manual Handling Assessment Chart (MAC Tool) method has a number of variables to be considered, namely coupling, load/ frequency, body posture, environmental factors, the state of the floor surface, carrying distance, obstacles on the route, also communication and co-ordination between the workers [26]. REBA method needs some variables to be considered, namely posture (trunk, neck, upper arms, legs, lower arms, wrist), coupling, and load [27].

There were 18 work postures that were assessed using REBA and 11 manual material handling activities that were evaluated using MAC Tool. If a work activity has a REBA score of more than 7 (classified as Action class 3) or a MAC score of more than 12 (classified as Action class 3) then the work activity will get recommendations for improvement. The improvement recommendations are given by considering the ergonomics approach to improve the work posture of the workers by re-designing the work station or by providing 
assistive devices. The improvement recommendation data were subsequently transferred to a mannequin in CATIA software, then the ergonomic intervention data will be assessed using REBA and MAC Tool to compare the risk level of before and after the improvement.

\subsection{Rapid Entire Body Assessment (REBA)}

The first step to collect the data was by recording the work activity using a camera. This was followed by measuring the angular dimension using Corel Draw X7 Software. The work activity was then assessed using Rapid Entire Body Assessment Method. The assessment of work posture by the REBA method in the research has several stages. The first stage is to assess the worker's posture on the trunk, legs, and neck to get the score of 'table A'. The second step is to get a 'score A' by summing up the load score and the score of 'table $A^{\prime}$. In the third stage, the working posture of the lower arms, upper arms, and wrist was assessed and was carried out to obtain a 'table B' value. The fourth stage is to obtain the 'score B' by summing up the coupling score to the value of the 'table B'. In the fifth stage, a meeting point from the 'score A' and 'score B' was recorded in 'table C'. Furthermore, summing up the value of 'table $\mathrm{C}$ ' and the activity scores was performed to get the 'score C'. The final step is to determine the level of risk from the work postures based on the 'score C'. The classification of work posture assessment by the REBA method [27] can be seen in Table 1.

Table 1:Work Posture Assessment by the REBA Method

\begin{tabular}{cccl}
\hline $\begin{array}{c}\text { REBA } \\
\text { Score }\end{array}$ & Risk Level & $\begin{array}{c}\text { Action } \\
\text { Level }\end{array}$ & \multicolumn{1}{c}{ Level } \\
\hline 1 & Negligible & 0 & None necessary \\
$2-3$ & Low & 1 & May be necessary \\
$4-7$ & Medium & 2 & Necessary \\
$8-10$ & High & 3 & Necessary soon \\
$>11$ & Very High & 4 & Necessary Now \\
\hline
\end{tabular}

\subsection{Manual Handling Assessment Chart Tool (MAC Tool)}

The MAC tool helps the researcher in assessing the most common risk factors in lifting and lowering, the carrying process and team handling. This tool was developed to identify high-risk manual handling. The MAC tool will direct the researcher to the factors that need to be modified to control risk [26]. Regarding the application of the MAC tool in this research, all the manual material handling processes were recorded using a camera; the illuminance and noise data were recorded using an environmental tester; the temperature data was collected using a thermometer; the distance data was obtained using a metric tape measure; and the load data was acquired using a scale.

What follows are stages of evaluating the manual material handling process using the MAC tool method [28].

a. Identify the variables of manual material handling activities following the type of operation (lifting, carrying or team handling). b. Categorize the score of each variable following the color band (color classification) so that the score of each variable is obtained.

c. Sum up the entire variable score to get the MAC score.

d. Using Table 2 of risk classification, determine the risk level of the manual material handling process based on MAC scores.

Table 2: Determination of the risk level and reforming actions in the MAC method

\begin{tabular}{clc}
\hline $\begin{array}{c}\text { MAC Final } \\
\text { Score }\end{array}$ & \multicolumn{1}{c}{ Reforming Action } & $\begin{array}{c}\text { Action } \\
\text { Class }\end{array}$ \\
\hline $0-4$ & No action demanded & 1 \\
$5-12$ & Action demanded in the near future & 2 \\
$13-20$ & Action demanded shortly & 3 \\
$21-31$ & Action demanded immediately & 4 \\
\hline
\end{tabular}

\section{RESULTS AND DISCUSSION}

\subsection{Rapid Entire Body Assessment}

In the process of making flour in UD Jaya Group, 18 work activities were assessed using the Rapid Entire Body Assessment method. The results of the Rapid Entire Body Assessment are presented in Table 3.

Based on Table 3, there was one work activity that falls into the action level 1, namely sweeping the flour activity at the drying work station. It means the work activity was classified as having a low-risk level and the activity might require improvements in the future.

There are 15 work activities falling into the action level 2 category. The activities are those of pouring raw materials, cleaning the flour and putting materials into sacks, all of which are carried out at the washing work station; smoothing the material with a shovel, moving the material to the grinding machine, inserting the milled material into the sack and transporting the sack to the cart, all of which are performed at the grinding work station; unloading sacks from carts and putting dry flour into sacks, two of which are done at the drying work station; moving flour sacks, taking the flour, and pouring flour on a milling machine, all of which are carried out at the smoothing work station; and activities carried out at the packing work station, namely the activities of taking the flour, pouring the flour into the sack and moving the sack of flour. All of these work activities had a moderate risk level and necessary improvements in the future are needed.

There are 2 work activities falling into the action level 3 category, namely the activity of moving the sack to the grinding work station carried out at the washing work station and the activity of spreading flour at the drying work station. These activities had a high level of risk and, therefore, immediate improvements were needed. 
Hafidh Munawir et al., International Journal of Emerging Trends in Engineering Research, 8(7), July 2020, 3720 - 3727

Table 3: Recapitulation of REBA Assessment

\begin{tabular}{|c|c|c|c|c|c|}
\hline $\begin{array}{l}\text { Work } \\
\text { station }\end{array}$ & Work Activities & $\begin{array}{l}\text { REBA } \\
\text { Score }\end{array}$ & $\begin{array}{c}\text { Risk } \\
\text { Level }\end{array}$ & $\begin{array}{c}\text { Action } \\
\text { Level }\end{array}$ & Action \\
\hline \multirow{4}{*}{ Washing } & Pouring raw materials & 5 & Medium & 2 & Necessary \\
\hline & Cleaning the flour & 7 & Medium & 2 & Necessary \\
\hline & Putting the materials into sack & 4 & Medium & 2 & Necessary \\
\hline & Moving the sack to the grinding work station & 10 & High & 3 & Necessary Soon \\
\hline \multirow{4}{*}{ Grinding } & Smoothing the material with a shovel & 6 & Medium & 2 & Necessary \\
\hline & Moving the material to the grinding machine & 6 & Medium & 2 & Necessary \\
\hline & Inserting the milled material into the sack & 4 & Medium & 2 & Necessary \\
\hline & Transporting the sack to the cart & 5 & Medium & 2 & Necessary \\
\hline \multirow{4}{*}{ Drying } & Unloading the sacks from the cart & 6 & Medium & 2 & Necessary \\
\hline & Spreading the flour & 9 & High & 3 & Necessary Soon \\
\hline & Sweeping the flour & 2 & Low & 1 & May Be Necessary \\
\hline & Putting the dry flour in a sack & 7 & Medium & 2 & Necessary \\
\hline \multirow{3}{*}{ Smoothing } & Moving the sack of flour & 5 & Medium & 2 & Necessary \\
\hline & Taking the flour & 6 & Medium & 2 & Necessary \\
\hline & Pouring flour into a milling machine & 6 & Medium & 2 & Necessary \\
\hline \multirow{3}{*}{ Packing } & Taking the flour & 6 & Medium & 2 & Necessary \\
\hline & Pouring the flour into the sack & 4 & Medium & 2 & Necessary \\
\hline & Moving the sack of flour & 5 & Medium & 2 & Necessary \\
\hline
\end{tabular}

Table 4:Recapitulation of MAC Tool Assessment Results

\begin{tabular}{clccc}
\hline \multirow{2}{*}{$\begin{array}{c}\text { Work } \\
\text { station }\end{array}$} & \multicolumn{1}{c}{ Work Activities } & $\begin{array}{c}\text { Score } \\
\text { MAC }\end{array}$ & Action Reform & $\begin{array}{c}\text { Action } \\
\text { Class }\end{array}$ \\
\hline \multirow{3}{*}{ Washing } & Cleaning the flour & 12 & Action demanded in the near future & 2 \\
\cline { 2 - 5 } & Putting the materials into the sack & 9 & Action demanded in the near future & 2 \\
\cline { 2 - 5 } & Moving the sack to the grinding work station & 22 & Action demanded immediately & 4 \\
\hline \multirow{3}{*}{ Grinding } & Moving the material to the grinding machine & 11 & Action demanded in the near future & 2 \\
\cline { 2 - 5 } & Inserting the milledd material into the sack & 7 & Action demanded in the near future & 2 \\
\cline { 2 - 5 } & Transporting the sack to the cart & 9 & Action demanded in the near future & 2 \\
\hline \multirow{3}{*}{ Drying } & Unloading the sacks from the cart & 12 & Action demanded in the near future & 2 \\
\cline { 2 - 5 } & Putting the dry flour in a sack & 10 & Action demanded in the near future & 2 \\
\cline { 2 - 5 } & Putting the sack on the cart & 11 & Action demanded in the near future & 2 \\
\hline Smoothing & Transfering the flour to a milling machine & 11 & Action demanded in the near future & 2 \\
\hline Packing & Moving the flour into the sack & 12 & Action demanded in the near future & 2 \\
\hline
\end{tabular}

\subsection{The Assessment of Manual Handling Assessment Chart (MAC Tool)}

In the process of making flour in UD Jaya Group, 11 work activities were assessed using the MAC Tool method. The MAC Tool assessment results are presented in Table 4.

Based on Table 4, there are 10 work activities classified as action level 2, namely cleaning the flour and putting the materials into a sack, two of which are carried out at the washing work station; moving the material to the grinding machine, inserting the milled material into the sack and transporting the sack to the cart, all of which take place at the grinding work station; unloading the sacks from the cart, putting the dry flour into the sacks, and putting the sacks onto the cart, all of which are performed at the drying work station; transferring flour to a milling machine taking place at the smoothing work station; and moving flour into the sack carried out at the packing work station.

\subsection{The Improvement Recommendations}

Based on the results of the assessment of the work posture with the Rapid Entire Body Assessment method and the results of the manual material handling assessment using the MAC Tool method, it is found that there were 2 work activities having a high level of risk (see Table 5). As a consequence, the workers experienced musculoskeletal discomfort. To avoid musculoskeletal discomfort and to reduce the level of risk, improvements are needed. The following paragraphs outline the recommended improvements. 
Table 5: WorkActivities Which Given the Improvement

\begin{tabular}{clcc}
\hline No & Work Activities & $\begin{array}{c}\text { REBA } \\
\text { Score }\end{array}$ & $\begin{array}{c}\text { MAC } \\
\text { Score }\end{array}$ \\
\hline 1 & $\begin{array}{l}\text { Moving the sack to the grinding } \\
\text { work station }\end{array}$ & 10 & 22 \\
\hline 2 & Spreading the flour & 9 & - \\
\hline
\end{tabular}

a.The Activity of Moving the Sack to the Grinding Work Station

The following are recommendations for improvement in the activity of moving sacks to the grinding work station

1) Reducing the weight of the sack

The weight of the sack moved by the worker is $40 \mathrm{~kg}$. The weight is considered unsafe based on the MAC Tool method. It is recommended to reduce the weight of the transferred sack to $18 \mathrm{~kg}$, quite safe weight. Jacob et al reported that a heavy unit increased the handling duration and muscular fatigue in the parlor milking workers, therefore workload reduction was achieved by not using a milking cluster that exceeds $2.4 \mathrm{~kg}$ [29].

\section{2) Adding the lights in the washing work station}

The washing work station has illuminance level of 123.1 Lux. The minimum illuminance level for manual and continuous work based on the Minister of Health's decision No. 1405 / MENKES / SK / X1 / 2002 is 200 lux. Therefore the lighting in the washing work station is considered not good. The level of the lighting can be improved by adding a few lights in the washing work station to improve the illuminance uniformity since it will decrease the risk of musculoskeletal disorder [30]. In a study by Aaras et al. [30], the workplace was given a new lighting system which increases the illuminance level from 300 lux to above 600 lux. The result shown that there was a significant decrease of neck, back and shoulder pain.

\section{3) Moving the sack with the trolley tools}

The activity of moving a sack to the grinding work station is not safe in terms of work posture or manual material handling. In this activity, the worker lifted the sack on his back without any tools. This caused the worker's back to bend when moving the sack. To reduce the level of risk in this activity, it is recommended that a tool such as a trolley will make it easier for workers to move the sack to the grinding work station. The process of moving the sack by using a trolley is considered to be more effective because in one cycle it can load 3 sacks, while the process of manually moving a sack can only move one sack. The proposed trolley has a medium size, thus the workers do not handle excessive loads. The trolley design recommendation is shown in Figure 1. Hasalkar et al [31] evaluated the process of topdressing fertilizer with the traditional method and the use of improved trolley. Their result highlighted that the use of the improved trolley reduces the percentage of the workers complaining about the musculoskeletal discomfort by $75 \%, 91.42 \%, 47.83 \%, 68.85 \%$ and $72.72 \%$ in the upper arm, shoulder joints, low back, knees, and wrist, respectively.

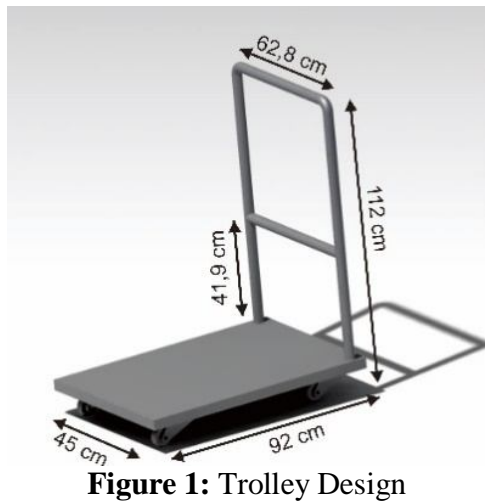

Figure 2 provides a comparison between the process of moving the sacks before and after the intervention.

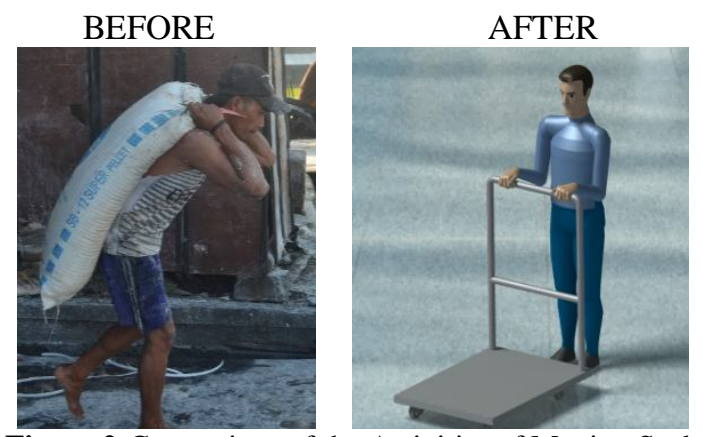

Figure 2:Comparison of the Activities of Moving Sacks

\section{b. Spreading Flour Activity}

The activity of spreading flour is considered unsafe in terms of work posture. This activity is carried out by the workers without assistive devices. In this case, the workers were squatting while spread the flour using their hands. To reduce the level of risk in this activity, it is recommended to use a tool that will be able to spread the flour properly. The tool design proposed in this paper is shown in Figure 3. The recommended tool will enable the workers to spreading the flour with less risk and reduce non-ergonomic work postures such as bending and squatting down. The tool will change the work posture of the workers to standing which is generally a preferred posture. This was in agreement with a study conducted by Gallagher [32] which found that the squatting posture is the least stable one compared to the other restricted postures while the standing posture appeared to be the highest psychophysically acceptable posture for loads compared to the other work postures. 
Hafidh Munawir et al., International Journal of Emerging Trends in Engineering Research, 8(7), July 2020, 3720 - 3727

Table 6: Recapitulation of the REBA Assessment Results Before and After Improvement

\begin{tabular}{lcccc}
\hline & \multicolumn{2}{c}{ REBA score } & \multicolumn{2}{c}{ Decrease } \\
\cline { 2 - 5 } Work Activities & $\begin{array}{c}\text { Before } \\
\text { Improvement }\end{array}$ & $\begin{array}{c}\text { After } \\
\text { Improvement }\end{array}$ & $\begin{array}{c}\text { Score } \\
\text { Percentage } \\
(\%)\end{array}$ \\
\hline Moving the sack to the grinding work station & 10 & 4 & 6 & 60 \\
\hline Spreading the flour & 9 & 2 & 7 & 77.8 \\
\hline
\end{tabular}

Table 7: Recapitulation of MAC Assessment Results Before and After Improvement

\begin{tabular}{lccc}
\hline & \multicolumn{2}{c}{ MAC score } & \multicolumn{2}{c}{ Decrease } \\
\cline { 2 - 4 } Work Activities & $\begin{array}{c}\text { Before } \\
\text { Improvement }\end{array}$ & $\begin{array}{c}\text { After } \\
\text { Improvement }\end{array}$ & $\begin{array}{c}\text { Score } \\
\text { Percentage } \\
(\%)\end{array}$ \\
\hline Moving the sack to the grinding work station & 22 & 8 & 14 \\
\hline
\end{tabular}

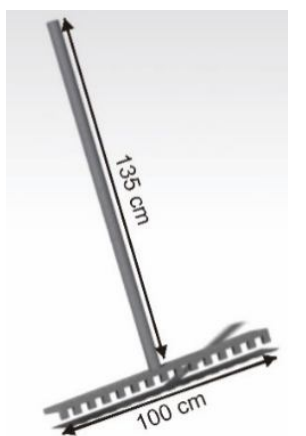

Figure 3:The Tool Design

A comparison between the process of moving the sacks before and after the intervention is available in Figure 4.
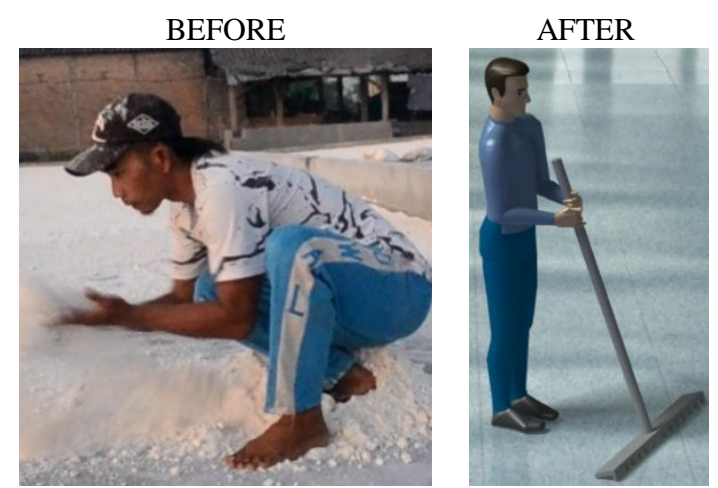

Figure 4: Comparison of the Flour Spreading Activity

\subsection{The Improvement Results}

Re-assessment was conducted on the proposed improvements using the REBA and MAC methods. Table 6 and Table 7 provide the recapitulation of the reassessment simulation results.

Based on Table 6, the risk levels of all work activities have decreased after the interventions. The work activity of moving the sack to the grinding work station before and after the improvement has a REBA score of 10 (classified as action level 3 with high risk), and of 4 , respectively. The results of the improvement showed a significant reduction on the risk by $60 \%$. The work activity of spreading flour before the improvement had the REBA score of 9 (classified as the action level 3 with high risk). After the improvement, this activity had the REBA score of 2 , meaning that this work activity was classified as action level 1 with a low-risk level. The results of improvement showed a risk reduction of $77.8 \%$. This study is in agreement with that conducted by Suhardi et al. on applying a new tool to improve the work posture among the furniture industry workers [33]. In their study, a reduction of risk level from a high-risk level (REBA score of 9 to 10) to a low-risk level (REBA score of 2 to 3 ) was resulted.

Table 7 consolidates the results related to the activity of moving the sack to the grinding work station. The activity had the MAC score of 22 before the improvement, meaning that immediate improvements were required (which classified as action class 4). After the improvement,the same activity had the MAC score of 8 , a low level of risk activity. The results of the improvement showed a significant reduction on the risk equalling $63.6 \%$.

Overall, the results of this study indicate that the ergonomic interventions successfully reduced the risk of musculoskeletal disorders among workers in UD Jaya Grup. These findings are consistent with a recent study [34] which depicted that designing a new tool as an ergonomic intervention reduced the risk of being afflicted by musculoskeletal disorders caused by manual material handling in the tile industry.

\section{CONCLUSION}

Based on the results of research and analysis of the data that has been presented, it can be concluded as follows:

a.The results of the assessment of work posture using the Rapid Entire Body Assessment (REBA) method in 18 work activities of flour production process obtained 1 work activity belonged to the action level 1 (low-risk level) 
category, 15 work activities belonged to the action level 2 category (level medium risk) and there were 2 work activities classified in the action level 3 category (high-risk level).

b. The results of the manual material handling assessment using the Manual Handling Assessment Chart (MAC Tool) method in 11 work activities of flour production process obtained 10 work activities classified as the action class 2 meaning that these work activities need improvements in the future and there was 1 work activity classified as the action class 4 meaning that the work activities need an immediate improvement.

c.Based on the assessment of work postures, there were 2 work activities that had a high risk of causing musculoskeletal disorder, namely the activity of moving sacks to the grinding work station and the activity of spreading flour. Based on the manual material handling assessment, there was one work activity that had a high risk of causing musculoskeletal disorder, that was the activity of moving the sack to the grinding work station.

d. The improvement recommendations for the activity of moving the sack to the grinding station were reducing the weight of the transferred load, adding lights at the washing work station and moving the load with trolley. The improvement recommendation for the activity of spreading the flour were using a tool as shown in Figure 3.

\section{REFERENCES}

1. Marsela."Addition of pineapple skin flour (ananas comosus) in making muffins process Penambahan tepung kulit nanas (ananas comosus) dalam pembuatan muffin-", Associate Degree thesis, Dept. Cullinary Art,Politeknik Negeri Balikpapan, Balik Papan, Indonesia, 2017.

2. D. Stambolian, M. Eltoukhy, and S. Asfour, "Development and validation of a three dimensional dynamic diomechanical lifting model for lower back evaluation for careful box placement", International Journal of Industrial Ergonomics, Vol. 54, pp. 10-18, 2016.

doi: 10.1016/j.ergon.2015.12.005.

3. A. Matebu and B. Dagnew, "Design of manual material handling system through computer aided ergonomics: a case study at bdtsc textile firm", International Journal for Quality Research, Vol.8, Num. 4, pp. 557-568, 2014.

4. Tarwaka,S. H. Bakri, and L. Sudiajeng,"Ergonomics: for safety, occupational health and productivity-ergonomi: untuk keselamatan, kesehatan kerja dan produktivitas", Published by UNIBA PRESS, Surakarta, 2004.

5. W. Nurdiati, G. T. Utami, and S. Utami, "The effect of stretching exercises on reducing pain intensity among nurses who suffer from low back pain- Pengaruh latihan peregangan terhadap penurunan intensitas nyeri pada perawat yang menderita low back pain", Jurnal Online Mahasiswa, Vol. 2, Num. 1, pp. 600-605, 2015.
6. R. M. Yusuff, and N. R. Abdullah, Ergonomics as a lean manufacturing tool for improvements in a manufacturing company, in Proc. of the 2016 International Conference on Industrial Engineering and Operations Management, Kuala Lumpur, 2016, pp. 581-588.

7. A. Klussmann, F. Liebers, H. Gebhardt, M. A. Rieger, U. Latza, and U. Steinberg, "Risk assessment of manual handling operations at work with the key indicator method (KIM-MHO) - determination of criterion validity regarding the prevalence of musculoskeletal symptoms and clinical conditions within a cross-sectional study", BMC Musculoskeletal Disorders, Vol. 18, Num. 184, pp. 1-13, 2017. doi: 10.1186/s12891-017-1542-0.

8. S. Ghosh, A. Bagchi, D. Sen, and P. Bandyopadhyay,"Ergonomics: a bridge between fundamentals and applied research", Indian Journal of Occupational and Environmental Medicine, Vol. 15, Num. 1, pp. 14-17, 2011. doi: 10.4103/0019-5278.83000.

9. A. Zaheer, and R. Khalid, "Ergonomics: a work place realities in Pakistan", International Posture Journal of Science and Technology, Vol. 2, Num. 1, pp. 1-11, 2012.

10. T. Mahardika, and D. Pujotomo, "Designing work facilities to reduce musculoskeletal disorders (msds) complaints with rapid entire body assessment method among paving and brick manufacturing workers in ukm usaha baru - Perancangan fasitilas kerja untuk mengurangi keluhan musculoskeletal disorders (msds) dengan metode rappid entire body assessment pada pekerja pembuatan paving dan batako pada ukm usaha baru",J @ TI Undip: Jurnal Teknik Industri, Vol. 9, Num. 2, pp. 109-116, 2014. doi: 10.12777/jati.9.2.109-116

11. H. Muzakki, "evaluasi beban dan postur kerja pada proses pengecoran logam dengan pendekatan ovako working analysis system (owas)- work load and posture evaluation in metal casting process with ovako working analysis system (owas) method", Jurnal Ilmiah Mikrotek, Vol. 1, Num. 1, pp. 17-22, 2013.

12. S. M. Qutubuddin, S. S. Hebbal, and A. C. S. Kumar, "An ergonomic study of work related musculoskeletal disorder risks in indian saw mills", IOSR (International Organization of Scientific Research) Journal of Mechanical and Civil Engineering, Vol. 7, Num. 5, pp. 7-13, 2013. doi: 10.9790/1684-0750713.

13. A. Nikulin, D. Ikonnikov, and I. Dolzhikov, "Increasing labour safety on coal mines",International Journal of Emerging Trends in Engineering Research (IJETER), Vol. 7, Num. 12, pp. 842-848, 2019. doi: 10.30534/ijeter/2019/197122019

14. S. Esmaeilzadeh, E. Ozcan, and N. Capan, "effects of ergonomic intervention on work-related upper extremity musculoskeletal disorders among computer workers: a randomized controlled trial", International Archives of Occupational and Environmental Health, Vol. 87, Num. 1, pp. 73-83, 2014. doi: $10.1007 / \mathrm{s} 00420-012-0838-5$ 
15. S. Ray, Introduction to materials handling, Published by New Age International (P) Limited, New Delhi, 2008.

16. H. Mohammadi et al, "Manual material handling assessment among workers of iranian casting workshops", International Journal of Occupational Safety and Ergonomics, Vol. 19, Num. 4, pp. 675-681, 2013. doi: 10.1080/10803548.2013.11077021.

17. R. D. Astuti, S. Susmartini, and A. P. Kinanthi, Improving the work position of worker based on manual material handling in rice mill industry, in the 3rd International Materials, Industrial and Manufacturing Engineering Conference, Miri, 2017, pp. 1-9. doi: 10.1063/1.5010660

18. L. Punnett, and D. H. Wegman, "Work-related musculoskeletal disorders: the epidemiologic evidence and the debate", Journal of Electromyography and Kinesiology, Vol. 14, pp. 13-23, 2004. doi: 10.1016/j.jelekin.2003.09.015.

19. H. C. Godwin, and D. U. Ndubueze, "Work-related musculoskeletal disorders among workers in brick making factory and building construction sites: an overview", International Journal of Engineering Research and Technology (IJERT), Vol. 2, Num. 6, pp. 552-577, 2013.

20. B. M. Tinubu, C. E. Mbada, A. L. Oyeyemi, and A. A. Fabunmi, "Work-related musculoskeletal disorders among nurses in ibadan, south-west nigeria: a cross-sectional survey", BMC Musculoskeletal Disorders, Vol. 11, Num. 12, pp. 1-8, 2010.

doi: 10.1186/1471-2474-11-12.

21. J. S. Boschman, H. F. Molen, J. K. Sluiter, and M. H. Fringsdresen, "Musculoskeletal disorders among construction workers: a one-year follow-up study", BMC Musculoskeletal Disorders, Vol. 13, Num. 196, pp. $1-9,2012$.

doi: 10.1186/1471-2474-13-196

22. W. L. Kim, and S. B. Lim, "Smart chair cover for posture correction", International Journal of Emerging Trends in Engineering Research (IJETER), Vol. 7, Num. 8, pp. 191-196, 2019. doi: 10.30534/ijeter/2019/14782019

23. W. J. Meerding, W. Ijzelenberg, M. A. Koopmanschap,J. L. Severens, and A. Burdorf, "Health problems lead to considerable productivity loss at work among workers with high physical load jobs", Journal of Clinical Epidemiolog, Vol. 58, Num. 5, pp. 517-523,2005. doi: 10.1016/j.jclinepi.2004.06.016

24. H. Brenner, and W. Ahern, "Sickness absence and early retirement on healthgrounds in the construction industry in ireland", Occupational and Environmental Medicine, Vol. 57, Num. 9, pp. 615-620, 2000. doi: 10.1136/oem.57.9.615.

25. G. LeMasters, A. Bhattacharya, E. Borton, and L. Mayfield, "Functional impairment and quality of life in retired workers of the construction trades", Experimental Aging Research, Vol. 32, Num. 2, pp. 227-242, 2006.

doi: 10.1080/03610730600554065.
26. Health and Safety Executive, Manual handling assessment charts (the MAC tool), 2014, available at www.hse.gov.uk/pubns/indg383.pdf

27. S. Hignett, and L. Mcatamney, "Rapid entire body assessment (REBA)", Applied Ergonomics, Vol. 31, pp. 201-205, 2000. doi: 10.1016/S0003-6870(99)00039-3.

28. S. Shokri, S. Varmazyar, and A. S.Varyani, "Manual material handling assessment and repetitive tasks with two methods MAC and ART in a subsidiary of a manufacturer of cleaning products article original article manual material handling assessment and repetitive tasks with two methods MAC and ART", Scientific Journal of Review, Vol. 4, Num. 8, pp. 116-123, 2015.

doi: 10.14196/sjr.v4i8.1899.

29. M. Jacob, F. Liebers, and S. Behrendt, "The effects of working height and manipulated weights on subjective strain, body posture and muscular activity of milking parlor operativese -laboratory study", Applied Ergonomics, Vol. 43,Num. 4, pp. 753-761,2012. doi: 10.1016/j.apergo.2011.11.009

30. A. Aaras, G. Horgen, H. Bjorset, O. Ro, and H. Walsoe, "Musculoskeletal, visual and psychosocial stress in vdu operators before and after multidisciplinary ergonomic interventions - a 6 years prospective study part II', Applied Ergonomics, Vol. 32, Num. 6, pp.559-571, 2001. doi: 10.1016/s0003-6870(01)00030-8

31.S. Halsakar, R. Shivalli, and R. Budihal, "Musculoskeletal disorders of the farm women while performing the top dressing of fertilizer activity", Journal of Human Ecology, Vol. 21, Num. 2, pp. 109-112, 2007.

doi: 10.1080/09709274.2007.11905958

32. S. Gallagher, "Physical limitations and musculoskeletal complaints associated with work in unusual or restricted postures: a literature review", Journal of Safety Research, Vol. 36, Num. 1, pp. 51-61, 2005.

doi: 10.1016/j.jsr.2004.12.001.

33. B. Suhardi, R. D. Astuti, and A. T. Widodo, Design of polishing tools for improving work posture in furniture industry, in Joint International Conference on Electric Vehicular Technology and Industrial, Mechanical, Electrical and Chemical Engineering (ICEVT \& IMECE) 2015, Surakarta, 2015, pp. 223-228. doi: 10.1109/ICEVTIMECE.2015.7496678

34. A. Dormohammadi, H. Amjad, M. Motamedzade, R. Dormohammadi, and S. Musavi, "Ergonomics intervention in a tile industry: a case of manual material handling", Journal of Research in Health Sciences, Vol. 12, Num. 2, pp. 109-113. 2012. 